\title{
SEMIÓTICA E LEITURA EM TEXTOS MIDIÁTICOS: PERSPECTIVA METODOLÓGICA
}

\author{
Tânia Regina Montanha Toledo Scoparo ${ }^{1}$
}

\begin{abstract}
Resumo: Propomos, neste trabalho, um Roteiro de atividades de leitura e interpretação dos discursos de dois textos midiáticos, romance e filme homônimo Lavoura Arcaica, sob a luz da semiótica discursiva para o verbal narrativizado e para a fílmica transmutada para o sincretismo verbo-visosonoro. A teoria semiótica tem oferecido instrumentos apropriados para uma leitura compreensiva do sentido de textos. As maneiras pelas quais ela propóe esse sentido levam à interpretaçâo segura das linguagens verbal, não verbal e sincrética. Pensamos que um trabalho com textos midiáticos, mais especificamente, com análise de textos literários transmutados para o cinema, pode nos apontar estratégias que viabilizem um melhor trabalho de formação de leitor da educação básica.
\end{abstract}

Palavras-chave: Semiótica. Leitura. Discurso. Textos midiáticos

\section{SEMIOTICS AND READING IN MEDIA TEXTS: METHODOLOGICAL PERSPECTIVE}

\begin{abstract}
We propose, in this work, a script of activities of reading and interpreting of the discourses of two media texts, novel and homonymous film Lavoura Arcaica, under the light of discursive semiotics for the narrativized verbal and for the filmic transmuted to the syncretism verb-visosonorous. Semiotic theory has offered appropriate tools for a comprehensive reading of the meaning of texts. The ways in which she proposes this sense lead to the safe interpretation of verbal, nonverbal, and syncretic languages. We think that a work with media texts, more specifically, with the analysis of literary texts transmuted into the cinema, can point us to strategies that make viable a better work of training the reader of basic education.
\end{abstract}

keywords: Semiotics. Reading. Discourse. Media texts.

1 Doutorado em Estudos da Linguagem pela Universidade Estadual de Londrina - UEL, (Brasil, 2017). Compõe a Equipe Técnica da Secretaria Estadual da Educação do Paraná - SEED. Compõe Grupo de Pesquisa da Universidade Estadual do Norte do Paraná - UENP, (Departamento de Letras). 


\section{INTRODUÇÃO}

Pensando em uma noção mais ampla do ato de ler, como um ato de atribuir sentido aos variados tipos de textos (verbais, visuais, sonoros), nas diversas experiências com a linguagem que interagem no cotidiano, propomos, neste trabalho, uma atividade de leitura em dois textos midiáticos, Lavoura Arcaica, romance (1975), texto verbal de Raduan Nassar; e filme (2001), texto verbo-visosonoro de Luiz Fernando Carvalho, com vistas à inserção do sujeito no contexto sócio-histórico em que vive. Para isso, elaboramos um Roteiro semiótico de ensino de leitura desses textos, com atividades de compreensão e interpretação, para alunos do ensino médio de escolas públicas estaduais da educação básica. A leitura desses gêneros textuais pode servir de mote para a leitura de outros textos que circulam na esfera social para formar alunos conscientes e críticos, possibilitando-lhes uma visão melhor do mundo e de si mesmos.

Uma das funções da escola é propiciar a formação do aluno em leitura de textos de qualquer natureza. Há inúmeros estudos e produções científicas sobre o assunto, trabalhados sob diferentes abordagens, como Bakhtin (1992, 1999), Brait (2005), Rojo $(2000,2009,2013)$, entre vários outros. No entanto, continua sendo um desafio o seu ensino e ainda há possibilidades de novas abordagens sobre o tema, principalmente, no tocante à leitura do texto visual, ou verbo-viso-sonoro, textos sincréticos ${ }^{2}$. Neste último caso, em particular, é preciso uma atenção maior pelo professor.

Apesar de inúmeros textos que circulam na esfera social serem compostos de duas ou mais linguagens (verbal, visual, sonora), como textos publicitários, programas de televisão, filme, revistas, livros infantis, etc, o ensino de leitura ainda se resume, nas escolas, ao texto verbal. Os livros didáticos trazem inúmeras imagens imbricadas com as atividades, mas, normalmente, essas são tratadas como ilustrativas, não havendo necessariamente leitura compreensiva do texto visual, como observamos em mais de vinte anos de exercício em sala de aula.

Em uma sociedade contemporânea, no século XXI, permeada de textos com imagens significativas, o ensino de leitura na escola não pode mais se restringir somente ao texto verbal, sem comprometer a compreensão integral das

2 Semióticas sincréticas, consoante Greimas e Courtés (s/d, p. 426), são aquelas que: “[...] como a ópera ou o cinema - acionam várias linguagens de manifestação; da mesma forma, a comunicação verbal não é somente de tipo lingüístico: inclui igualmente paralingüísticos (como a gestualidade ou a proxêmica), sociolingüísticos, etc.". Sobre essa questão, Discini (2005, p. 57) assevera: "no plano de conteúdo estão as vozes em diálogo, está o discurso. No plano da expressão está a manifestação do sentido imanente, feita por meio da linguagem sincrética, que integra o visual e o verbal sob uma única enunciação" e que juntos formem uma base comum sobre a qual se assenta a significação. Assim, as manifestações encontradas nos textos verbovisuais, audiovisuais, fotográficos, pictóricos, publicitários, entre outros, se organizam a partir de diferentes semióticas colocadas em relação. Nesses textos, o sentido é construído na combinação das várias linguagens amparadas simultaneamente no mesmo suporte textual, ou seja, diferentes linguagens manifestam-se ao mesmo tempo no plano da expressão, sendo o plano de conteúdo a base da significação desse discurso. 
variadas linguagens que circundam esses textos. Há necessidade de o aluno saber compreender textos verbais, assim como não verbais e os verbo-viso-sonoros, observando os efeitos de sentido que se produzem a partir da integração entre as diferentes linguagens, tornando-se, assim, proficiente, competente e crítico aos variados textos que o rodeiam.

Assim, torna-se importante o professor ser capacitado no processo de leitura e ter domínio de uma metodologia adequada à abordagem de textos que contêm, em sua manifestação, as mais variadas linguagens. Nesse contexto, a teoria semiótica discursiva é eficaz, se sua aplicação for adequada, para a construção de sentido desses textos, por ser uma teoria geral da significação, abarcando, em seus estudos, outras linguagens além da verbal. Neste trabalho, abarcamos, especificamente, em atividades de leitura, a enunciação, a sintaxe e a semântica discursivas. Também inserimos alguns aspectos técnicos da linguagem do cinema, os diferentes materiais de expressão e seus significados utilizados pelo diretor na construção de uma obra cinematográfica tendo por base um texto literário.

O trabalho justifica-se pela importância da leitura e interpretação de textos midiáticos, considerando essa perspectiva como enriquecedora para a formação do sujeito-leitor da educação básica, nas escolas estaduais, como postulam os Parâmetros Curriculares Nacionais (BRASIL, 1998, p. 40): "O trabalho com a leitura tem como finalidade a formação de leitores competentes" e estes precisam saber "utilizar as diferentes linguagens verbal, musical, matemática, gráfica, plástica e corporal como meio para produzir, expressar e comunicar suas idéias, interpretar e usufruir das produções culturais, em contextos públicos e privados, atendendo a diferentes intenções e situações de comunicação" (BRASIL, p. 7-8).

\section{SEMIÓTICA E LEITURA: MEDIAÇÃO POSSÍVEL}

A leitura para a semiótica, segundo Greimas e Courtés (s/d, p. 251-252), é uma semiose, ou seja, uma atividade que correlaciona um conteúdo a uma expressão dada, e transforma uma cadeia de expressão em uma sintagmática de signos:

tal performance pressupõe uma competência do leitor, comparável, ainda
que não necessariamente idêntica, à do produtor do texto. Se, no momento
da leitura normal, o fazer receptivo e interpretativo do leitor-enunciatário
continua implícito, sua explicitação, sob forma de procedimentos de análise
estabelecidos tendo em vista a reconstrução do sentido (informado e
mediatizado pelo significante), constitui tarefa da semiótica textual (narrativa e
discursiva). Nessa perspectiva, entende-se por leitura a construção, ao mesmo
tempo sintáxica e semântica, do objeto semiótico que explica o texto-signo.

Dessa forma, a leitura é constituída por dois papéis centrais, ou seja, há duas posições frente à leitura: uma que observa um leitor inscrito no texto, que é a figura do enunciatário, segundo a semiótica, e há também outra voltada para a ação, considerando um leitor externo ao texto no ato da leitura. A semiótica vê o enunciatário não como um leitor real, mas como um destinatário implícito da enunciação. O próprio texto faculta o contorno do leitor a partir de características 
discursivas. O leitor passa a ser um coenunciador, uma vez que é ele quem vai designar a escolha dos elementos que irão tecer o texto. Nesse sentido, em semiótica, o leitor-enunciatário é o destinatário da comunicação e também sujeito que produz o discurso, por isso o resultado do ato de leitura é produto de uma criação, um ato de linguagem em que o leitor produz significação "Durante o processo de leitura, o leitor produz uma sequência de atos de representação que vão sendo confirmados ou descartados na medida em que mantêm ou não a coerência de sentido do texto" (CORTINA, 2004, p. 166).

Assim, na enunciação, há um sujeito que produz o discurso, o enunciador, e aquele para quem o discurso é produzido, o enunciatário. Este cumpre o papel de destinatário sujeito ao ser manipulado cognitiva e pragmaticamente pelo enunciador, mesmo que o fazer almejado não se concretize. $O$ fazer persuasivo do enunciador busca uma resposta do fazer interpretativo do enunciatário, por meio de um contrato que estabelece como o enunciatário deve fazer a interpretação da verdade do discurso.

A interpretação depende, assim, da aceitação do contrato fiduciário e, sem dúvida, da persuasão do enunciador para que o enunciatário encontre as marcas de veridicção do discurso e as compare com seus conhecimentos e convicções, decorrentes de outros contratos de veridicção, e creia, isto é, assuma as posições cognitivas formuladas pelo enunciador. $\mathrm{O}$ enunciador não produz discursos verdadeiros ou falsos, mas constrói discursos que criam efeitos de sentido de verdade ou de falsidade, que parecem verdadeiros. $\mathrm{O}$ parecer verdadeiro é interpretado como ser verdadeiro, a partir do contrato deveridicção assumido (BARROS, 1988, p. 94).

Nesse sentido, assumindo o contrato, o leitor se constitui como um destinatário da comunicação e um sujeito que produz o discurso, um coenunciador capaz de desvelar os sentidos do texto de forma consciente e crítica, ou como Bertrand (2003, p. 24) anuncia, um leitor que se constitui em um ser no centro do discurso, que "constrói, avalia, aprecia, compartilha ou rejeita as significações".

É esse coenunciador que irá, nas aulas de leitura literária, leitura fílmica, por exemplo, transformar-se no sujeito do fazer em busca dos diferentes e vários significados que os textos produzem. No texto literário, ele precisa dar conta da linguagem verbal e todas as suas diferentes combinações expressivas que organizam um texto estético.

Já num texto fílmico, o coenunciador se depara com o sincretismo de linguagens, as combinações significativas articulam-se por meio da linguagem oral dos diálogos dos atores, a linguagem cinematográfica das imagens que compõem o espaço, a linguagem musical das trilhas sonoras e os diversos sons que perpetram o universo do cinema.

Literatura e cinema são artes que não se repelem, aproximam-se na fruição e despertam e aprimoram a sensibilidade estética e as dimensões da leitura. Tanto no discurso literário quanto no cinematográfico, as categorias ficcionais, as temáticas, as técnicas de produção e criatividade artística fazem parte dos elementos 
estruturados dos dois discursos. A busca por novas linguagens, como o tratamento dado ao tempo e ao espaço, em textos, por exemplo, de Kafka, Joyce e Proust, são métodos e técnicas adotados pelo cinema. Faz parte da natureza humana criar e recriar o mundo e, no percurso, o homem desenvolve novas formas de expressão, novas linguagens e tecnologias para expressar seus sentimentos, sua razão e emoção (PALMA, 2004, p. 7).

A concepção de leitor desses dois objetos culturais como um coenunciador exige uma postura metodológica interdisciplinar, uma interação das muitas modalidades discursivas para aumentar e dinamizar as suas competências, oferecendo-lhes condições reflexivas de aprofundamento e integração de linguagens. Nesse sentido, pode-se, portanto, dinamizar e aprofundar as leituras estabelecendo entre os dois discursos, literatura e cinema, diálogos possíveis.

As duas modalidades artísticas apropriam-se de um leitor/espectador que almeja encontrar na página/tela uma narrativa ficcional: a construção de um espaço, onde alguma coisa acontece, e de uma ação, organizada num enredo, que se desenrola colocando em conflito as personagens ao longo de um determinado tempo; a sucessão das ações se faz por meio do discurso, formando uma série de enunciados postos em sequência. Apesar de apresentarem suportes diferentes, as duas manifestações preveem a presença de leitores e espectadores, indispensáveis para a atualização dos textos, visto que tanto um como o outro não possuem uma única perspectiva, ou seja, apontam diferentes pontos de vista com os quais o leitor/espectador pode atualizar as respectivas construções artísticas.

Nessa perspectiva, a discursivização aplicada aos textos literários permite ao leitor perceber a arquitetura narrativa subjacente a todo e qualquer tipo de texto, entre eles o fílmico, sob as mais diversas roupagens figurativas. Além disso, a semiótica greimasiana permite conciliar o exame de outras linguagens envolvidas na produção de um filme. Os procedimentos de análise para o texto verbal, visual ou sincrético são bastante semelhantes. De modo geral, entende-se que um texto deva ser descontruído na análise, intentando a compreensão das estratégias utilizadas para a produção de sentido.

Apesar de a teoria greimasiana não ser ensinada na escola pública e nem fazer parte das atividades dos livros didáticos, acreditamos que alguns de seus conceitos podem contribuir para o entendimento do funcionamento discursivo, em qualquer situação discursiva, conforme atesta Limoli (et al., 2003, p. 1):

Os conceitos básicos e os princípios de análise da teoria greimasiana, adaptados às capacidades e necessidades dos alunos, tornam-se um instrumental de grande eficácia no ensino de leitura. As ferramentas de análise da teoria semiótica mostram-se extremamente performantes, contribuindo para a formação de alunos com maior capacidade de entendimento do texto escrito. O rigor e a objetividade de análise, previstos pela teoria semiótica, desenvolvem não apenas as potencialidades de compreensão no sentido estrito, mas contribuem consideravelmente, também, para o domínio linguístico do aluno, a capacidade de formulação de idéias e a conseqüente melhoria da participação nas práticas sociais mediadas pela linguagem. 
Dessa forma, esses conceitos possibilitam a apropriação dos sentidos veiculados nos textos pelos alunos da educação básica, desde que a didatização proceda apoiada em objetos de estudo que atendam às expectativas dos adolescentes.

Enfim, a Semiótica dá conta das relações entre enunciador e enunciatário, das implicações do leitor no processo de leitura, das relações intersubjetivas presentes na troca da comunicação. A teoria possui, também, enorme potencial de análise do não verbal e sincrético, requisito básico para o tratamento de textos multimodais, escapando ao tratamento puramente icônico e analógico da imagem, como atestam Greimas e Courtés (s/d, p. 336):

A semiótica planar - que trata da fotografia, do cartaz, do quadro, da história em quadrinhos, da planta de arquiteto, da escrita caligráfica, etc. - tenta estabelecer categorias visuais específicas do nível da expressão, antes de considerar sua relação com a forma do conteúdo.

Limoli (2006, p. 68) corrobora essa assertiva ao dizer que "analisar a imagem significa apreciá-la em sua dupla leitura, icônica e plásica". Nesse sentido, falar sobre cromatismo, categorias eidéticas, textura, suporte, enquadramento, etc, devem fazer parte das atividades em sala de aula.

Sendo assim, a Semiótica insere-se no rol das teorias que podem trazer contribuições significativas ao ensino de leitura de textos verbais e não verbais.

Nesse sentido, a proposta, para este trabalho, converge para uma apreensão educativa, a leitura, e realiza-se alicerçada no campo da educação e da comunicação, especialmente, a literatura e o cinema, por meio de uma base comum, a teoria semiótica, para levantar e organizar apontamentos para a elaboração de um Roteiro ${ }^{3}$ semiótico de leitura de textos literários e fílmicos para alunos do ensino médio de escolas públicas estaduais da educação básica. Entretanto, não rejeitamos a ideia de uma adaptação para aplicar no trabalho com alunos de outros níveis. É possível que haja uma mudança de romance com outra transmutação fílmica, aplicando a mesma didática para esses novos objetos - corpus mais acessível aos estudantes do ensino fundamental.

\section{SUGESTÁO DE UMA PROPOSTA METODOLÓGICA SISTEMATIZADA PARA LEITURA}

Nesta proposta, não temos intenção de fornecer receita pronta e acabada que possa sanar as dificuldades já existentes com a leitura nas salas de aulas da educação básica. Demonstraremos que é possível um trabalho com as mídias romance e filme, utilizando a semiótica greimasiana para expor os sentidos imanentes desses objetos.

3 Roteiro no sentido de abordar tópicos importantes a serem discutidos, refletidos, em uma apresentação oral ou escrita (HOUAISS, 2001, p. 2477). 
Não é uma proposta estanque, como mencionado, abarca a metodologia semiótica greimasiana, e outras, sugeridas pelos autores Discini, 2012; Teixeira, 2009; Fiorin, 1992 e 1996; e os aportes teóricos do cinema em Ismail Xavier, 2005; Marcel Martin, 2003. Apresentamos uma sistematização dessas metodologias em um Roteiro de leitura para o romance e o filme, com atividades de análise e interpretação desses textos, assim como, também, ao final, uma produção textual.

Denominamos nossa proposta de "Roteiro semiótico para leitura de textos verbal e verbo-viso-sonoro", e buscamos, nesse Roteiro, aprofundar, por meio da leitura de textos literários e fílmicos, a capacidade de compreensão e interpretação desses textos para formar o pensamento crítico e a sensibilidade estética, permitindo a expansão lúdica da leitura. Vejamos a proposta:

\section{Roteiro semiótico para leitura de textos verbal e verbo-viso-sonoro}

- Objetos de leitura: livro e filme Lavoura Arcaica, de Raduan Nassar e Luiz Fernando Carvalho, respectivamente.

- Utilização da teoria semiótica do texto ${ }^{4}$ a teoria propõe uma leitura imanente do texto, ou seja, a leitura de qualquer texto se organiza a partir dos elementos concretos que o constituem - tanto aspectos linguísticos, considerando os textos verbais, quanto eidéticos (relativos às formas), cromáticos, topológicos, sonoros, etc., pensando nos textos visuais e verbo-viso-sonoros.

- É necessário observar o seguinte ao ler os textos e assistir ao filme:

- Nas estruturas discursivas dos textos: observar as projeções de pessoa, tempo e espaço, as relações entre um enunciador (autor pressuposto) e um enunciatário (leitor/espectador inscrito no discurso), os temas e as figuras (palavras e expressões que representam as coisas do mundo).

- No plano de conteúdo do romance e do filme: observar o que o texto diz e como ele faz para dizer o que diz, atentando ao significado do texto;

- No plano de expressão do filme: observar a manifestação do conteúdo em um sistema de significação verbal, não verbal ou sincrético (textos entendidos como formas textuais que integram visual e verbal na mesma enunciação como ocorre nos textos fílmicos, por exemplo). Atentar para os formantes figurativos - elementos que servem para criar

4 Nos livros Para entender o texto: leitura e redação (1992), Lições de texto: leitura e redação (1996), de Platão e Forin, e no livro Comunicação nos textos (2012), de Norma Discini, encontram-se muitas atividades exemplificando a utilização da teoria semiótica, por isso, neste trabalho, não colocaremos exemplos da enunciação, da sintaxe e da semântica discursivas, e partiremos para as atividades do romance e do filme, objetos de nossa análise. Se o professor quiser aprofundar o estudo sobre a teoria semiótica, sugerimos as leituras de Elementos de análise do discurso, de José Luiz Fiorin (2009) e Semiótica visual, de Antonio Vicente Pietroforte (2004). 
os efeitos de realidade dentro do discurso; as figuras do mundo que se identificam no discurso e procura-se dar sentido de acordo com o conhecimento que já se tem - e os formantes plásticos - categorias que possibilitaram a atribuição de novos sentidos aos textos, dão sentido ao plano de expressão, divididas nas categorias: topológica (ligada à posição), eidética (ligada às formas) e cromática (ligada às cores) ${ }^{5}$.

- No processo de transmutação: observar, entre a palavra do livro e os elementos do cinema, as interpretações possíveis co-presentes no texto literário que foram privilegiadas na elaboração fílmica pelo cineasta. Observar a interpretação orquestrada pelo diretor da obra do romance. Como o cineasta preservou um mesmo conteúdo em uma diferente forma.

- Na linguagem do filme: observar direção, enquadramento, planos, cor, fotografia, movimentos de câmeras, iluminação, cenário, ligações e transições, metáforas e símbolos, fenômenos sonoros (ruídos, música), diálogos, etc., para a produção de sentido.

\section{Reconhecendo o discurso dos textos}

\section{Enunciação e enunciado}

- Enunciação é ato produtor de enunciados; estes são as realizações linguísticas concretas.

- Cada locutor se coloca como sujeito ao apropriar-se da linguagem e se constituir por um "eu", que se dirige a um "tu".

- Ao enunciar, o sujeito constrói o enunciado e, ao mesmo tempo, constróise como sujeito.

- A pessoa enuncia em um determinado espaço e tempo; estes organizamse ao redor do $e u$.

5 Para a semiótica o semissimbolismo trouxe a possibilidade de um estudo mais ordenado das contribuições da expressão para o sentido do texto. Conforme Pietroforte (2004, p. 21), o semissimbolimo acontece quando o plano de expressão deixa de ser apenas uma forma de veicular o conteúdo e passa a "fazer sentido" a partir da articulação entre a forma de expressão e a forma de conteúdo. Assim, para Floch (2001) o semissimbolismo é o sentido construído na ligação entre plano de conteúdo e da expressão: “[...] Os sistemas semissimbólicos se definem pela conformidade não entre os elementos isolados dos dois planos, mas entre categorias da expressão e do conteúdo. Há dois princípios básicos usados por Algirdas Julien Greimas e JeanMarie Floch para analisar essa manifestação do semissimbolismo, os quais no plano de expressão podem ser revelados: os formantes figurativos - elementos que servem para criar os efeitos de realidade dentro do discurso; são as figuras do mundo que se identificam no discurso e dão sentido de acordo com o conhecimento que já se tem - e os formantes plásticos - categorias que possibilitaram a atribuição de novos sentidos aos textos, dão sentido ao plano de expressão e de acordo com trabalhos de Greimas, Floch e Thürlemann, foram divididas nas categorias: topológica (ligada à posição), eidética (ligada às formas) e cromática (ligada às cores). 
- No ato de comunicação, o espaço aqui e o tempo agora opõem-se ao espaço lá e ao tempo então, que são próprios do ele; este não participa do ato de comunicação.

Enunciador e enunciatário

- Há dois papeis para o sujeito da enunciação: o de sujeito que arquiteta um objeto, o texto; e o de destinador (enunciador) que instala um destinatário (enunciatário) no discurso.

- No discurso, o enunciador exerce um fazer persuasivo sobre o enunciatário.

Processos sintáticos da enunciação

- No enunciado, encontram-se marcas que simulam a enunciação (enunciação enunciada).

- A enunciação é sempre pressuposta; a enunciação enunciada é um simulacro que reproduz, no interior do discurso, o fazer enunciativo: o "eu", o "aqui", ou o "agora", encontrados no discurso enunciado, não configuram as pessoas, o espaço e o tempo da enunciação.

- No enunciado, pode haver ausência de marcas que simulam a enunciação. Não há o eu, o aqui, e o agora, mas o ele, o lá, e o então.

Debreagem

- São as projeções de pessoas, de espaços e de tempos no enunciado.

- Projeção de pessoa:

a) Debreagem enunciativa: projeção no enunciado do $e u / t u$. Produz efeitos de subjetividade e de aproximação.

b) Debreagem enunciva: projeção no enunciado do ele. Produz efeitos de objetividade e de distanciamento.

c) Debreagem interna (projeção de $2^{\circ}$ grau - diálogos/discurso direto): simula a projeção do discurso das pessoas do enunciado ou da enunciação já instaladas no enunciado.

Assim, na projeção de pessoa, tem-se a delegação de vozes:

Quadro 01: Delegação de vozes

\begin{tabular}{|l|l|l|}
\hline Instâncias Pressupostas & Enunciador & Enunciatário \\
\hline $1^{\circ} \mathrm{Grau}$ & Narrador & Narratário \\
\hline $2^{\circ} \mathrm{Grau}$ & Interlocutor & Interlocutário \\
\hline
\end{tabular}

- Projeção de tempo (utilização de elementos linguísticos - dêiticos temporais adverbiais e verbais): 
a) Debreagem enunciativa: projeção no enunciado dos tempos que possuem o agora como referência temporal. Há efeito de subjetividade e de aproximação.

b) Debreagem enunciva: projeção no enunciado dos tempos que possuem o momento passado ou futuro como referência temporal. Há efeito de objetividade e de distanciamento.

- Projeção de espaço

a) Debreagem enunciativa: projeção no enunciado dos espaços dispostos em função do aqui. Há efeito de subjetividade e de aproximação.

b) Debreagem enunciva: projeção no enunciado dos espaços dispostos em função de um lá. Produz efeito de objetividade e de distanciamento.

Neutralizações

- Embreagem: neutralizações das oposições no interior da categoria de pessoa, de tempo ou de espaço. A neutralização é verificada pelo uso de uma pessoa no lugar de outra, no uso de um tempo no lugar de outro e no uso de um espaço no lugar de outro.

Ethos do enunciador

- Ethos: imagem do enunciador produzido pelas recorrências de um modo de dizer.

- Contribuem para a criação dessa imagem os procedimentos sintáticos, mas principalmente a construção semântica do discurso. É na perspectiva semântica que reconhecemos de forma mais acentuada as questões ideológicas do enunciador.

Processos semânticos da enunciação

- Textos figurativos (possuem termos mais concretos) e textos temáticos (possuem termos mais abstratos): Os textos podem ser mais abstratos ou mais concretos. A organização narrativa, que é comum a todos os textos, concretiza-se no discurso por elementos com diferentes graus de abstração.

- Temas e Figuras: perceber os temas e as figuras e seu encadeamento coerente são fundamentais para a produção de sentido de um texto.

- Figuras: termos que representam os seres, ações, etc. do mundo natural (ou mundo criado pelo discurso, a ficção, por exemplo).

- Temas: têm caráter conceptual e interpretam, organizam, categorizam os elementos do mundo natural.

- Normalmente, os textos apresentam temas e figuras, no entanto há predominância de um ou outro elemento (mais ou menos abstrato). 
- Os textos figurativos concretizam temas, portanto, ao ler um texto em que haja predominância de termos concretos, são necessários identificar os temas, para que a leitura seja realizada de modo menos superficial.

- Percursos temáticos e figurativos: Como o texto é um todo de sentido, as figuras e os temas subjacentes não estão isolados, mas correlacionam-se por meio de traços semânticos, de recorrências de sentido. Assim, não se devem interpretar os termos isoladamente para chegar ao sentido do texto, mas considerar as cadeias e percursos temáticos e figurativos que dão coerência aos textos.

- Isotopia: recorrência do mesmo traço semântico ao longo de um texto; oferece um plano de leitura para o leitor, determinando um modo de ler o texto.

\section{- Aplicando atividades}

- Usaremos fragmentos para desenvolver as atividades, mas os alunos devem ler o romance e assistir ao filme, obrigatoriamente.

- Sinopse da narrativa:

A narrativa mostra o encontro de dois irmãos, André e Pedro, em um quarto anônimo de pensão, na cidade, onde André se escondeu e se refugiou após abandonar a fazenda em que vivia com a família. O texto é dividido em duas partes. $\mathrm{Na}$ primeira, André rememora e desnuda suas experiências, distanciado no tempo, e procura explicar ao irmão mais velho, Pedro, sua fuga do campo. Seu relato sobre si mesmo opõe-se, numa comunicação ambígua, à força poderosa do pai, que leva a vida dedicada aos trabalhos com a terra e à contrição religiosa. Os capítulos se alternam entre o momento da narração e o passado na fazenda com a família. Nesse momento presente da narração, há uma visão profunda de sua solidão, envolvida pela lascívia do corpo, da carne, em um quarto escuro de pensão. O cenário, aqui, avulta de importância, assumindo a relação entre a personagem André e o seu drama: é apertado, sufocante, escuro. Nesse espaço, o irmão mais velho chega para tentar resgatá-lo para o seio da família novamente. Há um diálogo tenso entre eles. André faz inúmeras revelações, entre elas, o incesto praticado com a irmã Ana, deixando aflorar suas angústias em "um sopro escuro da memória" (p. 106). Na segunda parte do texto, André, convencido a voltar para casa "Pedro cumprira sua missão me devolvendo ao seio da família" (p. 149), propõe-se dialogar com o pai, expondo suas opiniões sobre a forma como ele conduz, tradicionalmente, a família. Acontece também, em uma festa para comemorar o retorno de André, o desenlace trágico, culminando no assassinato da irmã Ana pelo pai.

1. Leia os fragmentos abaixo do romance para responder as questões.

6 Usaremos várias vezes trechos do texto para exemplificar, por isso, desse ponto em diante, quando houver, após uma citação do romance Lavoura Arcaica, somente a página, trata-se da $3^{a}$ edição do romance, de Raduan Nassar, publicado em 1989 (originalmente em 1975), pela Editora Companha das Letras, São Paulo. 
Fragmento 1: "[...] dei logo uns passos e abri uma das folhas me recuando atrás dela: era meu irmão mais velho que estava na porta; assim que ele entrou, ficamos de frente um para o outro, nossos olhos parados, era um espaço de terra seca que nos separava, tinha susto e espanto nesse pó, mas não era uma descoberta, nem sei o que era, e não nos dizíamos nada, até que ele estendeu os braços e fechou em silêncio as mãos fortes nos meus ombros e nós nos olhamos e num momento preciso nossas memórias nos assaltaram os olhos em atropelo, e eu vi de repente seus olhos se molharem, e foi então que ele me abraçou, e eu senti nos seus braços o peso dos braços encharcados da família inteira; voltamos a nos olhar e eu disse "não te esperava" [...] e eu senti a força poderosa da família desabando sobre mim como um aguaceiro pesado enquanto ele dizia "nós te amamos muito, nós te amamos muito" e era tudo que ele dizia enquanto me abraçava mais uma vez; ainda confuso, aturdido, mostrei-lhe a cadeira do canto, mas ele nem se mexeu e tirando o lenço do bolso ele disse "abotoe a camisa, André" (Capítulo 1, p. 11).

Fragmento 2: "Na modorra das tardes vadias na fazenda, era num sítio lá do bosque que eu escapava aos olhos apreensivos da família; amainava a febre dos meus pés na terra úmida, cobria meu corpo de folhas e, deitado à sombra, eu dormia na postura quieta de uma planta enferma vergada ao peso de um botão vermelho; não eram duendes aqueles troncos todos ao meu redor, velando em silêncio e cheios de paciência meu sono adolescente? Que urnas tão antigas eram essas liberando as vozes protetoras que me chamavam da varanda? de que adiantavam aqueles gritos, se mensageiros mais velozes, mais ativos, montavam melhor o vento, corrompendo os fios da atmosfera? (meu sono, quando maduro, seria colhido com a volúpia religiosa com que se colhe um pomo) (capítulo 2, p. 13-14).

a) $\mathrm{O}$ romance apresenta ao leitor um sujeito, André, fragilizado e perturbado pela influência desestabilizadora da convivência com o pai. No fragmento 1, início do romance, André está em um quarto de pensão e, nesse espaço, o irmão mais velho, Pedro, chega para tentar resgatá-lo para o seio da família. Há um diálogo tenso entre eles. O que representa a figura do irmão para André? O que se depreende deste discurso do irmão: "abotoe a camisa, André".

b) Qual é o tipo de projeção de pessoa empregado nos fragmentos acima (enunciva ou enunciativa)? Qual é o sentido produzido por essa escolha?

c) A credibilidade do texto seria diferente se o enunciador utilizasse outra projeção? Você acreditaria mais ou menos na história de André se ela fosse narrada em outra projeção?

d) No fragmento 1, o narrador fala de seu presente ou de seu passado? Grife no texto alguns verbos que comprovem sua afirmação.

e) O passado influenciou a maneira como André estava se sentindo, no presente, no quarto de pensão? Explique. Retire, do fragmento 1, frases que comprovem sua resposta. 
f) Em sua opinião, o passado influencia na maneira como vivemos o nosso presente? Justifique sua resposta.

g) $\mathrm{Na}$ primeira parte da narrativa, André rememora suas experiências, distanciado no tempo, e procura explicar ao irmão mais velho, Pedro, sua fuga do campo. Pensando nisso, no fragmento 2, observamos uma dessas experiências no campo. $\mathrm{O}$ narrador fala do passado exatamente como ele foi ou ele fala de suas lembranças do passado? Existe diferença entre falar do passado exatamente como ele foi e falar das lembranças do passado?

h) Grife um verbo do fragmento 1 que mostre uma ação acabada e única (pontual). E do fragmento 2, um verbo que mostre uma ação que se repetia ou um hábito. Explique a utilização desses tempos para a construção dos dois textos.

i) Em meio à debreagem utilizada no discurso para construir a história, ainda há a operação de debreagens internas, também chamadas de $2^{\circ}$ grau. Isso ocorre quando o enunciador transfere a palavra às pessoas (interlocutores) do enunciado, criando a ilusão de situação "real". São os diálogos no texto, o discurso direto. Observe, no fragmento 1, o diálogo entre os irmãos. Nessa interlocução, temos um "eu", André, e um "ele", Pedro, projetados no discurso. Explique as debreagens utilizadas para provocar a sensação de presente no interior do tempo passado. Esse recurso provoca um efeito de verdade no discurso? Explique.

j) $\mathrm{O}$ narrador, quando fala do bosque, fragmento 2 , alude a um espaço datado e materializado no passado, no lá, e a partir de um espaço-tempo do passado que ele projeta um olhar sobre o presente, aqui, na pensão. Como esse espaço, da fazenda, no bosque, é ressignificado para André?

2. Leia alguns trechos de um diálogo do romance, retirado do capítulo 25:

\section{Fragmento 3:}

(André) “- Eu também tenho uma história, pai, é também a história de um faminto, que mourejava de sol a sol sem nunca conseguir aplacar sua fome, e que de tanto se contorcer acabou por dobrar o corpo sobre si mesmo alcançando com os dentes as pontas dos próprios pés, ele só podia odiar o mundo" (p.159-160).

(Pai) "Você sempre teve aqui um teto, uma cama arrumada, roupa limpa e passada, a mesa e o alimento, proteção e muito afeto. [...] Faça um esforço, meu filho, seja mais claro, não dissimule, não esconda nada do teu pai” [...] (p. 160).

$[\ldots]$

(André) “- Não se pode esperar de um prisioneiro que sirva de boa vontade na casa do carcereiro; da mesma forma, pai, de quem amputamos os membros, seria absurdo exigir um abraço de afeto; maior despropósito que isso só mesmo a vileza do aleijão que, na falta das mãos, recorre aos pés para aplaudir o seu algoz; age quem sabe com a paciência proverbial do boi: além do peso da canga, pede que 
lhe apertem o pescoço entre os canzis. Fica mais feio o feio que consente o belo" (p. 164).

\section{$[\ldots]$}

(Pai) “-Cale-se! Não vem desta fonte a nossa água, não vem destas trevas a nossa luz, não é a tua palavra soberba que vai demolir agora o que levou milênios para se construir; ninguém em nossa casa há de falar com presumida profundidade, mudando o lugar das palavras, embaralhando as idéias, desintegrando as coisas numa poeira, pois aqueles que abrem demais os olhos acabam só por ficar com a própria cegueira; ninguém em nossa casa há de padecer também de um suposto e pretencioso excesso de luz, capaz como a escuridão de nos cegar; ninguém ainda em nossa casa há de dar um curso novo ao que não pode desviar, ninguém há de confundir nunca o que não pode ser confundido, a árvore que cresce e frutifica com a árvore que não dá frutos, a semente que tomba e multiplica com o grão que não germina, a nossa simplicidade de todos os dias com um pensamento que não produz; por isso dobre a tua língua, eu já disse, nenhuma sabedoria devassa há de contaminar os modos da família! Não foi o amor, como eu pensava, mas o orgulho, o desprezo e o egoísmo que te trouxeram de volta à casa!” (p. 168-169).

a) No primeiro discurso do pai, no fragmento acima, há uma embreagem que suspende a oposição entre en e ele (ou tu), empregando-se a terceira pessoa (ou segunda) em lugar da primeira, comum em uma interlocução (debreagem interna de $2^{\circ}$ grau). Retire do texto um exemplo dessa embreagem na construção do discurso do pai.

b) Nesse diálogo há muitas figuras que recobrem ideias gerais e abstratas, os temas. Identifique as figuras (termos que retratam os seres, ações, etc. do mundo natural) que representam o discurso de André, e as que representam o discurso do pai.

André:

Pai:

c) Em um percurso figurativo, as figuras e os temas subjacentes não estão isolados, mas correlacionam-se por meio de traços semânticos, de recorrências de sentido. A partir das figuras encontradas no diálogo anterior, monte o quadro abaixo com o percurso figurativo e temático de André e do pai. 
Quadro 02: Percurso Figurativo e Temático

\begin{tabular}{|l|l|l|l|}
\hline \multicolumn{1}{|c|}{ Sujeitos/Ator } & \multicolumn{1}{|c|}{ Figuras } & $\begin{array}{c}\text { Percurso } \\
\text { Figurativo }\end{array}$ & \multicolumn{1}{|c|}{ Temas } \\
\hline André & Da & Da Revolta \\
\hline Pai & Da autoridade & $\mathrm{Da}$ \\
\hline & & & \\
\hline & & & \\
\hline
\end{tabular}

d) Isotopia é a recorrência do mesmo traço semântico ao longo de um texto; ela oferece ao leitor um plano de leitura, um modo de ler o texto. Percebemos pela leitura do romance, ou mesmo pelo capítulo 25, cujas partes do diálogo entre André e o pai estão no Fragmento 3, que a figuratividade presente na actorialização de André leva-nos a criar sentidos relacionados à sua fragmentação perante as situações vivenciadas com o pai. As figuras integram uma isotopia que leva o leitor a interpretála como representante dos temas propostos na narrativa do romance, que são liberdade e opressão, moderno e arcaico, paixão e moral, amor e morte, entre outros. Pense que são temas que correspondem ao universo real, que estão presentes na vida de qualquer um. Sendo assim, a qual isotopia temática se chegaria a partir dessa figuratividade? Comente.

3. Após assistir ao filme, observe as sequências de imagens, abaixo, retiradas do início do filme, para responder as questões. 
Figura 01 - Pedro e André

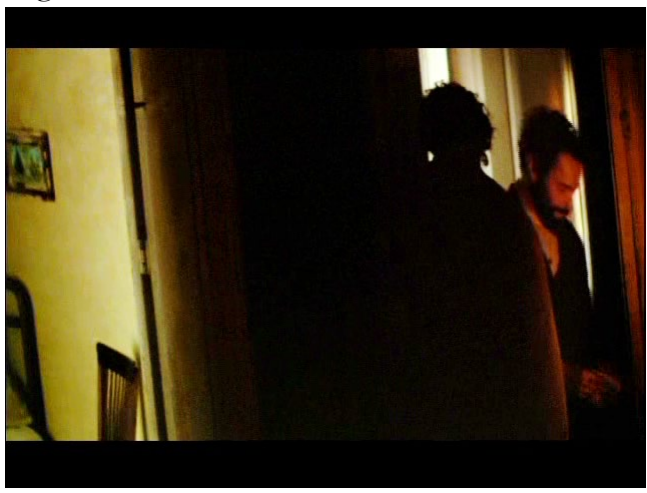

Figura 03 - André criança

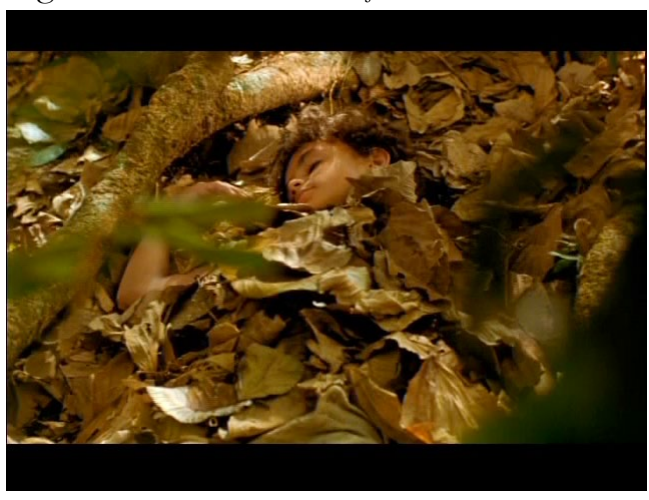

Figura 02 - Irmãos se abraçam

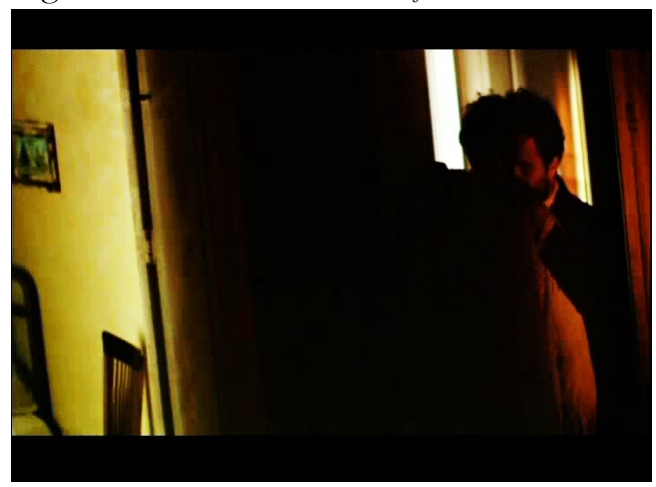

Figura 04 - Memórias

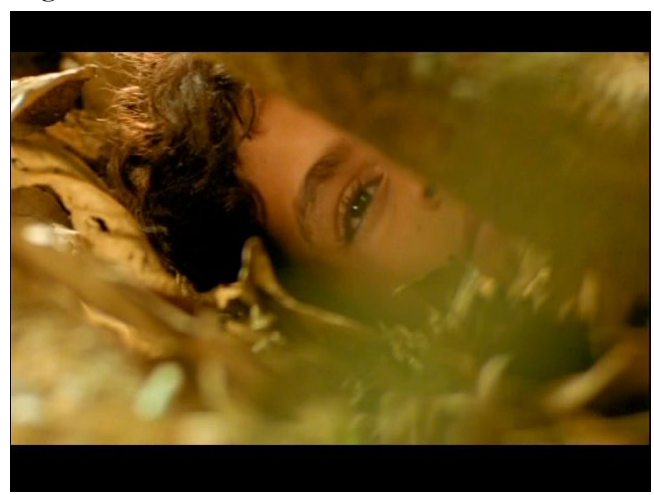

Fonte das imagens: DVD Lavoura Arcaica, 2001

a) As imagens 01 e 02 mostram a chegada do irmão Pedro, na pensão, para resgatar André ao seio da família; e as 03 e 04, uma lembrança de André em relação à infância, no bosque da fazenda. Essas imagens foram transmutadas pelo diretor do filme, Luiz Fernando Carvalho, e correspondem ao $1^{\circ}$ e $2^{\circ}$ capítulos do romance. Segundo o diretor, não há no filme um diálogo que não seja do romance, ou seja, optou-se pela fidelidade na trama da história, sobretudo pela densidade dos episódios relatados. Você acredita que um texto adaptado pode ser completamente fiel ao texto de partida? Comente.

b) Vejamos como se desenvolve a temporalização no filme. Na primeira sequência do filme, no quarto de pensão, representada pelas imagens 01 e 02 acima, percebemos uma objetividade aparente correspondente à debreagem enunciva (ele), quando se instala um tempo com status de "naquele momento". Na verdade, a debreagem de tempo (então) dessa sequência inicial do filme caracteriza-se por uma suposta debreagem temporal enunciva. Por que seria uma suposta debreagem enunciva? 
Justifique levando em consideração a seguinte afirmativa: o cinema é a arte do presente.

c) A partir do momento em que chega o irmão Pedro na pensão, e iniciam os diálogos, qual debreagem se instala no filme? Qual é o efeito de sentido?

d) Os fatos do passado introduzem o simulacro de enunciação, no filme, como no romance, há um ir e vir constante devido aos flashbacks. Dessa forma, quando, no início da narrativa, no quarto de pensão, André começa a contar suas ações na fazenda, na concomitância do presente, o recurso da embreagem enunciativa nos transporta para o interior de suas lembranças. Tais embreagens são apresentadas ao enunciatário por meio de recursos visuais. Como, por exemplo, na sequência das imagens acima, as quais representam dois momentos distintos: o presente da ação (imagens 01 e 02); e as memórias, (imagens 03 e 04). Qual (ou quais) recurso visual utilizado para demarcar o recuo temporal das memórias de André?

Leve em consideração a descrição desses recursos: flashbacks (as analepses), flashforwards (as prolepses), e há ainda os cortes (indica mudança de sequência, de cena, de plano ${ }^{7}$ ), os avanços e os recuos da câmera (travellings ${ }^{8}$ para frente ou para trás), fade-out (escurecimento da imagem) e a fusão (quando uma cena funde-se a outra). Outro recurso utilizado é o cromatismo das cenas: pouca ou muita luz e cores ou preto e branco servem para marcar a embreagem. Esses são recursos que o cinema utiliza para indicar a presentificação do passado e do futuro em qualquer momento de referência.

e) Nessas sequências, há dois espaços projetados: o quarto de pensão e o bosque da fazenda, este foi introduzido por meio das lembranças de André. Pensando na relação espaço-tempo do filme, como se instaura a categoria do espaço nessas sequências (debreagem enunciva e/ou enunciativa)? Para responder lembre-se que são dois momentos distintos, um no presente da ação e outro, no passado, são memórias. Qual é o sentido produzido por essas escolhas?

f) No filme, o diretor Luiz Fernando Carvalho é o enunciador, não o Luiz Fernando Carvalho real, de carne e osso, mas enquanto interpretação de sua obra, de seu estilo. Ele, juntamente com os integrantes da equipe

7 É na articulação dos planos que se deve produzir um sentido lógico e coerente para o texto visual. Xavier (2005, p. 27) assim explica: As sequências são unidades menores dentro do filme, marcadas por sua função dramática. Cada sequência é constituída de cenas (cada uma das partes de unidade espaço-temporal). Temos, então, a decupagem - processo de decomposição do filme em planos, os quais correspondem a cada tomada de cena, ou seja, à extensão de filme compreendida entre dois cortes, o que significa dizer que o plano é um segmento contínuo da imagem. 
técnica (roteirista, diretor de fotografia, de arte, assistente de direção, de montagem, etc) formam um só papel, ou seja, o ator da enunciação. Assim, ele é um autor implícito, um eu pressuposto, uma imagem construída pelo texto; e o eu projetado no interior do enunciado é o narrador. Nesse sentido, o narrador (imagem projetada do autor no enunciado), no filme, no caso, é explicitado? Sendo assim, qual é o tipo de projeção de pessoa empregado no filme (enunciva ou enunciativa)? Qual é o sentido produzido por essa escolha?

g) No plano do conteúdo, tanto no romance como no filme, tem-se a oposição semântica delineada pelos temas liberdade vs opressão, devido ao embate entre pai e filho. Na instância narrativa, liberdade é um objeto almejado por André, para fugir da autoridade arcaica e opressora do pai. Essa oposição semântica / liberdade / vs / opressão / que se estabelece na diegese do romance e do filme toma uma direção figurativa importante na sua relação com a imagem visual. Nas duas sequências em análise, nas imagens visuais, no plano da expressão, há um jogo de outras oposições que concretizam essa oposição principal do plano de conteúdo, delineada pelas figuras de André adulto e criança, do irmão (representante do pai) e os espaços (o quarto da pensão e o bosque), que figurativizam, no discurso, os temas da liberdade e da opressão.

Vamos analisar, nas imagens abaixo, essas oposições visuais. Complete o quadro abaixo com as oposições visuais que concretizam os temas liberdade vs opressão: Para isso, leve em consideração o seguinte:

Atentar para os formantes plásticos - categorias que possibilitaram a atribuição de novos sentidos aos textos, dão sentido ao plano de expressão, divididas nas categorias: topológica (ligada à posição), eidética (ligada às formas) e cromática (ligada às cores). 
Quadro 03: Oposições visuais

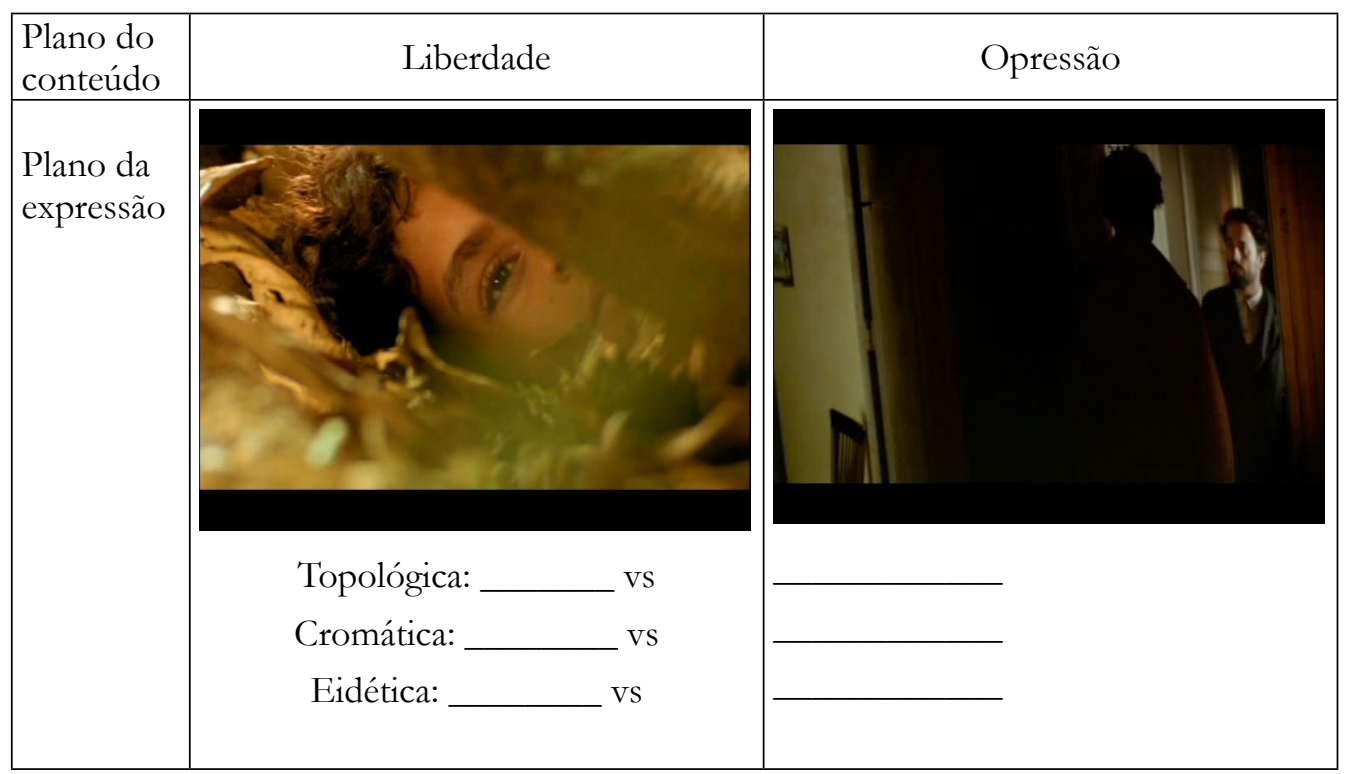

4. O espaço - o quarto de pensão e a fazenda - instala-se, tanto no romance como no filme, enredando-se com a trama. No romance, no início da narrativa, o narrador-personagem André já o coloca como um lugar "inviolável", íntimo, onde ele pode buscar sua individualidade, tanto necessária para sua sanidade. No filme, também observamos esse espaço como lugar íntimo, pessoal. Observe a sequência em que André vasculha uma caixa com quinquilharias mundanas, no quarto da pensão, e pede ao irmão entregá-las às irmãs. A sequência se passa em 1h11min de filme:

Figura 05 - Os irmãos no quarto de pensão Figura 06 - Caixa
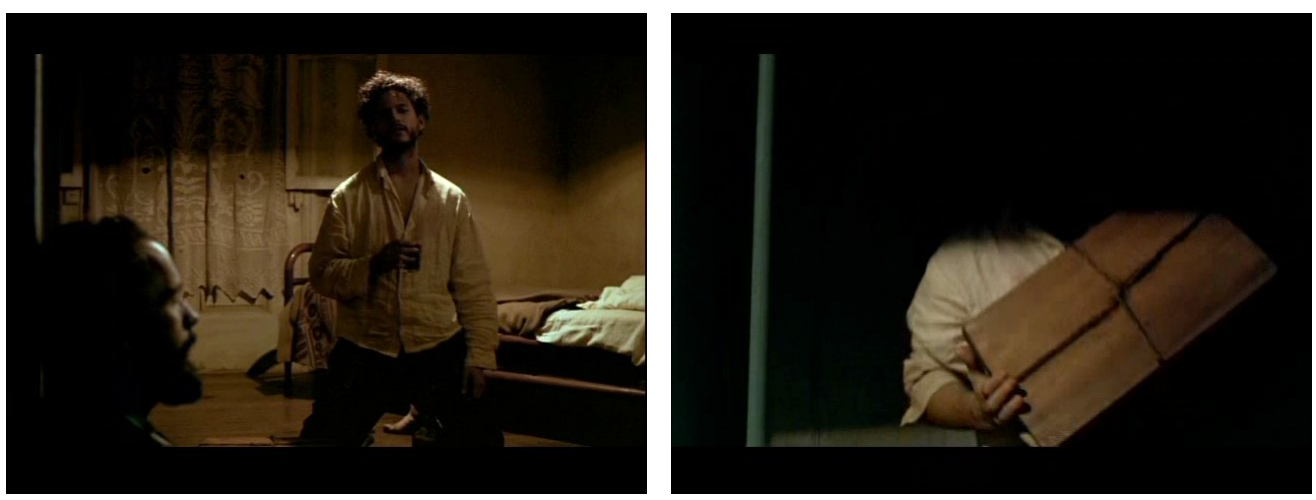
Figura 07 - Objetos

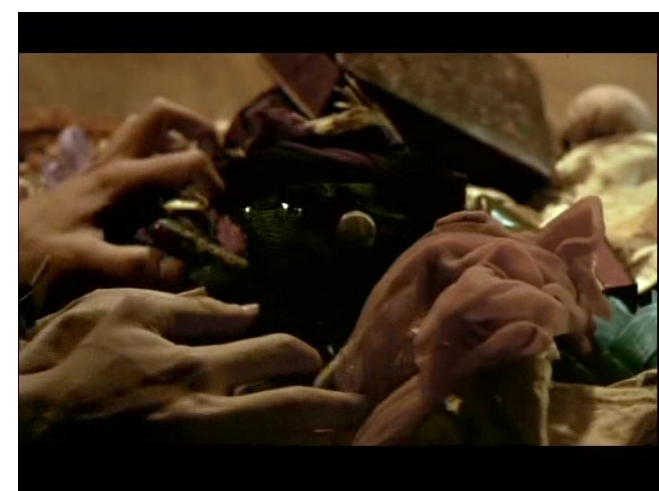

Figura 09 - André

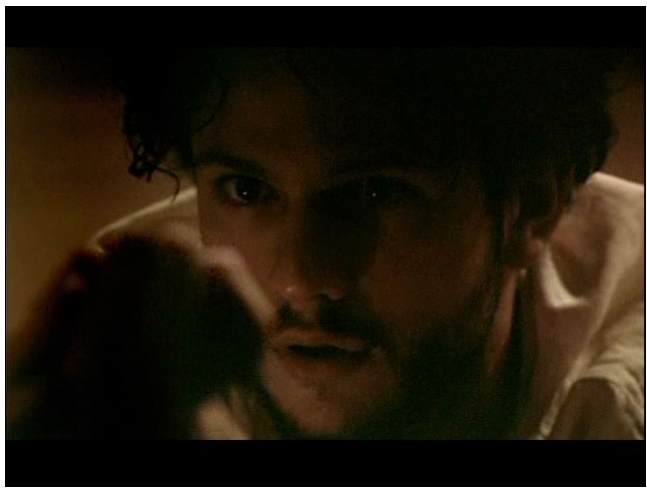

Figura 11 - Revolta

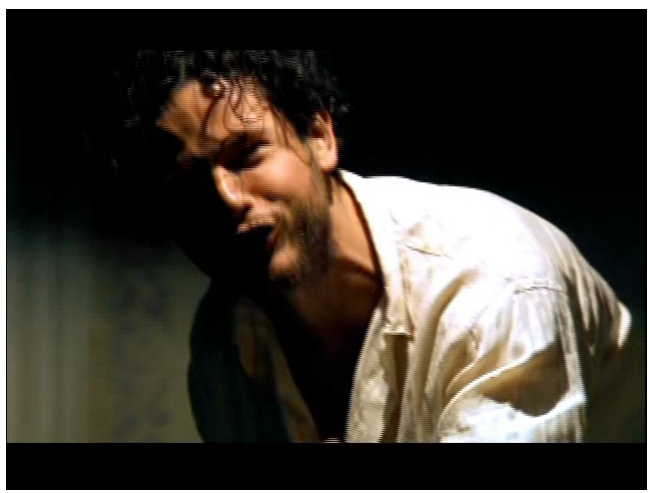

Figura 08 - Fitas

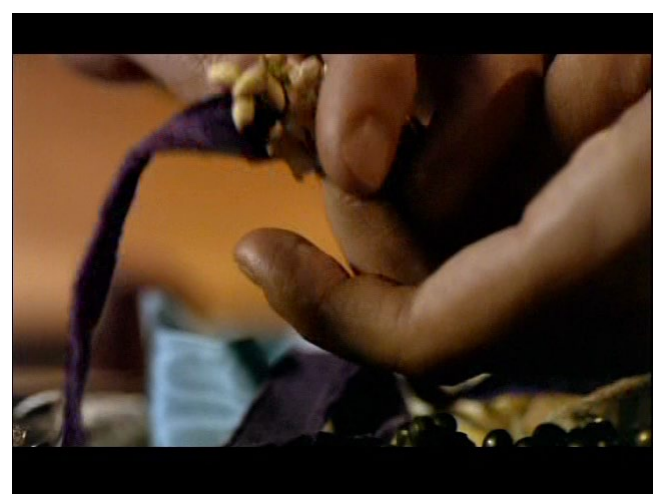

Figura 10 - Pedro

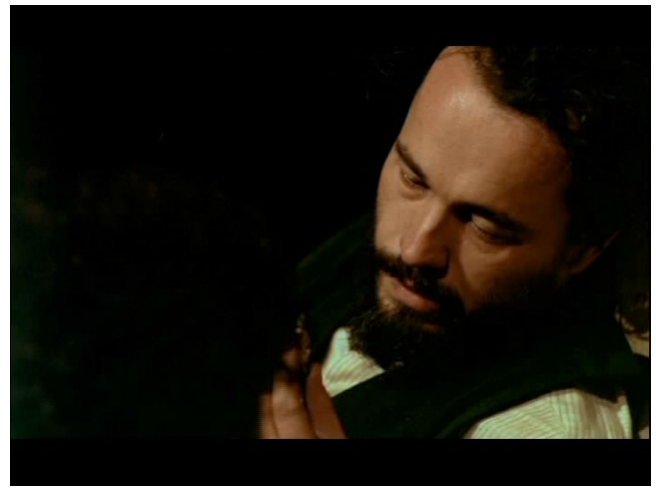

Figura 12 - Fúria

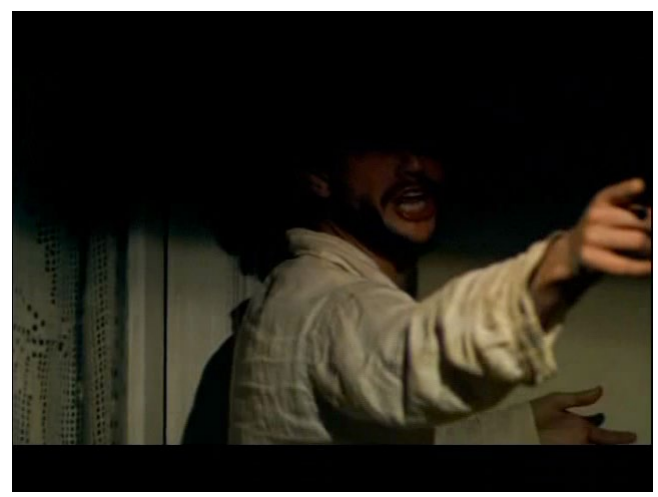


Figura 13 - Contraste

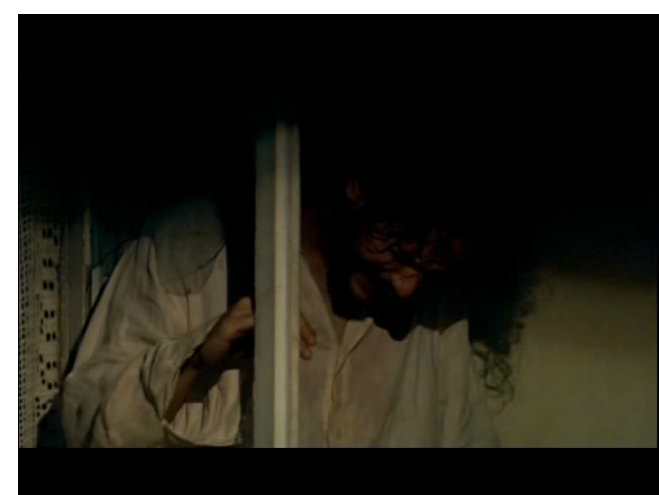

Fonte das imagens: DVD Lavoura Arcaica.
Figura 14 - Pedro triste

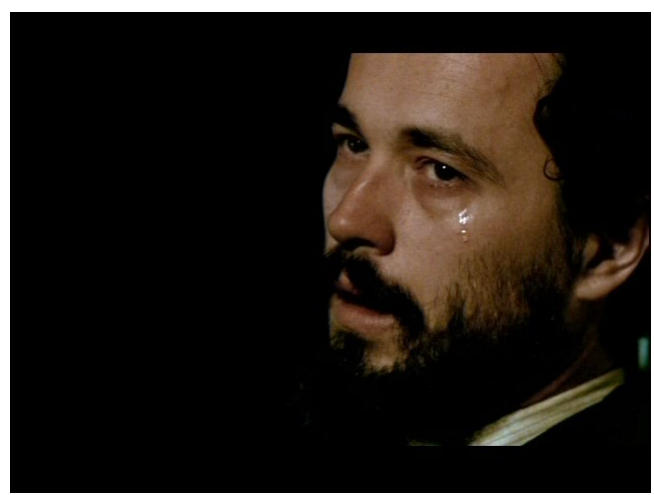

a) O espaço integra um grande choque de contrastes entre o cromatismo e o interior e exterior, figs 05 a 14, que se mesclam com um sentimento eufórico e um sentimento disfórico da personagem. Tem-se uma visão de espaços exteriores e interiores, e da manifestação do próprio corpo de André. A narrativa traduz a exterioridade e a interioridade de André, dos deslocamentos, não só da luz, mas dos estados de alma da personagem. Quais os elementos cromáticos contrastantes nessa sequência? Que recurso da linguagem do cinema ${ }^{9}$ foi usado para intensificar esse contraste? Exemplifique utilizando os fotogramas acima.

9 Aqui o professor pode chamar a atenção dos alunos para a iluminação e explicar os efeitos que ela produz: a iluminação, no cinema, obedece a uma estratégia, ajuda a compor um quadro, uma cena ou uma sequência. A técnica da iluminação pode ser aproveitada como um meio natural de dirigir a atenção do espectador para um determinado elemento específico do quadro, enquanto outros são obscurecidos. Constitui o principal operador anafórico do filme, e são inúmeras as possibilidades criativas: realizar contrastes, criar atmosferas, sugerir sentimentos, acentuar certas qualidades (positiva ou negativa) do interior das personagens (Martin, 2003). 
b) $\mathrm{Na}$ montagem, os planos $^{10}$ alternam-se para compor o quadro dessa sequência. Descreva a cena narrada, das imagens 5 a 10, utilizando o recurso dos planos para compor a significação fílmica. Exemplifique com as imagens.

c) $\mathrm{Na}$ sequência, há sons ${ }^{11}$ humanos: discurso de André e respiração ofegante, como também uma discreta música ao fundo. Esses elementos sonoros ajudam a compor o estado emocional da personagem? Explique.

d) Nessa sequência, André espalha os objetos de uma caixa e escolhe alguns para mostrar ao irmão, imagens 07 e 08 . Em meio às palavras, a câmera revela André se levantando abruptamente, imagem 11, alterando seu tom de voz, mais alta, nervosa, e ele esbarra na lâmpada do teto. Qual o efeito que o movimento da lâmpada produz na personagem de André, figs 12

10 Necessário, também, explicar a função e o sentido dos planos no cinema:

É na articulação dos planos que se deve produzir um sentido lógico e coerente para o texto visual. Xavier (2005, p. 28), ao tomar os conceitos de decupagem clássica, classifica quatro planos, que serão demostrados a seguir:

Plano geral: Insere o sujeito em um ambiente, eventualmente dando uma ideia das relações entre eles. Mostram cenas amplas, todo o espaço da ação. Abrange um campo maior de visão. As personagens parecem distantes de nosso olhar. Pode se tornar espetacular, quando visa a mostrar a grandeza das conglomerações humanas, a amplidão de uma paisagem.

Plano Médio ou de Conjunto: Mostra o conjunto de elementos envolvidos na ação (figuras humanas e cenário), principalmente em interiores (uma sala por exemplo). As personagens estão perto das margens do quadro fílmico. Esse plano pode assumir uma significação social, quando põe em relevo a relação de uma personagem com outras, com grupos, com a massa, com classes, com profissões, com a família. Também relaciona o indivíduo com um grupo ou a natureza, integrando o homem no mundo e na sociedade e, dependendo do contexto fílmico, faz dele a presa das coisas.

Plano Americano: Corresponde ao ponto de vista em que as figuras humanas são mostradas da cabeça até a cintura aproximadamente, em função da maior proximidade da câmera em relação a ela. É plano que aparece dominante em diálogos.

Primeiro Plano (close-up): A câmera, próxima da figura humana, focaliza um detalhe, um rosto ou uma mão, por exemplo. (Há uma variante chamada primeiríssimo plano, que se refere a um maior detalhamento - um olho, ou uma boca ocupando toda a tela). Esse plano costuma indicar ou sugerir uma invasão no mundo espiritual das personagens, mostra uma tensão mental intensa, aponta um sentimento opressor ou liberador. Dessa forma, possui função descritiva (detalhamento de feições ou de coisas) e explicativa (exploração psicológica das personagens).

11 O professor pode explicar os efeitos da música e do som:

A música age sobre os sentidos, como fator de intensificação e aprofundamento da sensibilidade, explicita implicações psicológicas de certas situações dramáticas, exprime uma apreciação subjetiva do acontecimento, intervém como contraponto psicológico para fornecer ao espectador um elemento útil à compreensão da tonalidade humana de um episódio.

O som coloca à disposição do filme um registro descritivo amplo, pode ser utilizado como contraponto ou contraste em relação à imagem. São várias as contribuições: aumenta o coeficiente de autenticidade da imagem, ou seja, a impressão da realidade; a trilha sonora restabelece a continuidade, tanto ao nível da percepção quanto ao da sensação estética; a voz em off torna possível a exteriorização dos pensamentos (monólogo interior); o silêncio sublinha com força a tenção dramática de um momento (símbolo de morte, perigo, solidão); entre muitas outras contribuições (MARTIN, 2003, p. 113-126). 
e 13? Articula-se aqui um paralelismo entre espaço interno e externo. Explique.

5. Momento de produzir o seu texto:

- Você está em uma capital, no Brasil. O ano é 2018. Imagine a cidade e o estado. Você está nesse lugar e nesse tempo. Esse é o momento de sua história, de seu discurso, o tempo é o agora (presente).

- Nesse espaço, você presencia uma crise de família, que vai desestabilizar o seu núcleo. Em forma do gênero memória, construa um texto em que você se recorda dos momentos felizes que vivia essa família (anterioridade em relação ao momento do discurso). Narre as consequências dessa crise para a família (posterioridade em relação ao momento do discurso). Não deixe de mencionar seus sentimentos, opiniões sobre a crise que presencia (concomitância em relação ao momento do discurso).

- No seu texto, os tempos estarão organizados em relação ao momento do discurso. Haverá, em seu texto, momentos do presente, do passado e do futuro.

- Lembre-se de que para escrever um texto, você precisa planejar, escrever e reescrever ${ }^{12}$, para isso se atente para:

o Planejamento: escolha o ponto de vista a ser tratado, pense no objetivo, a finalidade de seu texto, ordene suas ideias, preveja seus possíveis leitores, considere a situação em que o texto vai circular, esteja seguro quanto ao que pretende dizer.

o Escrita: coloque no papel o que planejou e atente-se para cumprir todos os itens planejados.

o Reescrita: reveja o que escreveu, confirme se os objetivos foram cumpridos, veja se há relação entre os períodos, entre os parágrafos, e entre os blocos superparagráficos, verifique se há clareza, fidelidade às normas da sintaxe e da semântica, conforme prevê a gramática da estrutura da língua, reveja pontuação, ortografia, divisão do texto em parágrafos. Enfim, faça a revisão do texto e a reescrita da melhor forma para dizer aquilo que se pretenda comunicar.

\section{CONSIDERAÇÓES FINAIS}

Todas as obras referentes à leitura possuem em comum um objetivo, o de melhorar o ensino de língua materna, no entanto, as perspectivas teóricas nas propostas de análise e ensino nem sempre são as mesmas. As diferenças evidenciam que não há um único olhar acerca da problemática do ensino. O mesmo acontece com o trabalho com a Semiótica, uma teoria que, como as outras, pode contribuir

12 Conforme Irandé Antunes, em Aula de português: encontro \& interação, 2009. 
para a abordagem do texto e auxiliar, aliada às outras, com o trabalho mais eficaz em relação à leitura dos diferentes textos presentes no cotidiano dos jovens.

Ao propormos um Roteiro semiótico de leitura de textos literários e fílmicos foi nossa intenção promover um diálogo entre as duas linguagens, literária e fílmica, verificando os mecanismos de construção de sentido mobilizados pelos dois textos, por meio de atividades de interpretação, e, a partir dessa construção, instrumentalizar os alunos do ensino médio para que leiam, compreendam e analisem, eficientemente, esses gêneros textuais, como também, os diferentes textos que circulam na esfera social, para se posicionarem criticamente diante das mensagens midiáticas deste século.

$\mathrm{O}$ arranjo entre as diferentes linguagens nas atividades propostas demanda modos particulares de leitura e produção de sentido. Os textos em questão exigem do leitor uma cooperação ativa, pois precisa de conhecimentos específicos sobre as linguagens verbal e verbo-viso-sonoras. $\mathrm{Na}$ articulação entre palavra e imagem, aciona-se o crivo poder-saber para fazer-querer-ler na atribuição de significados, manifestando, possivelmente, um leitor atento às combinações sincréticas do texto. O papel social do professor, diante desse contexto, é auxiliar, por meio de estratégias, a compreensão de si, do mundo e dos textos, utilizando uma prática de leitura que ao mesmo tempo emancipa o pensamento e humaniza o aluno, num todo.

Priorizamos aqui a leitura semiótica da palavra e da imagem, ou seu sincretismo, possibilitando a produção de sentido. Pressupomos que uma apropriação dessa vertente pode criar condições de aprendizagens que cinge outros tipos de textos, em suas combinações. Pensamos que essa proposta, se aplicada, pode oportunizar saber-ver, saber-ler, saber-sentir, saber-pensar e saber-criar novas particularidades de pensamento no processo de produção de sentido. Dessa forma, a leitura rompe limites das dificuldades colocadas pela linguagem verbal, para abarcar a diversidade de semioses e os efeitos produzidos.

A leitura de textos literários e fílmicos permite nos apontar estratégias que viabilizam um melhor trabalho de formação de leitor do ensino médio, mas salientamos, que é importante a adequação de material e de método - como o que a semiótica disponibiliza - à necessidade e dificuldade dos alunos. Esperamos que essa proposta seja aproveitada por professores, em suas aulas de língua portuguesa, e que haja futuros estudos que avaliem sua efetiva aplicação, inclusive com as eventuais dificuldades que possam surgir.

\section{REFERÊNCIAS}

ANTUNES, Irandé. Aula de português: encontro \& interação. São Paulo: Parábola Editorial, 2009.

BAKHTIN, M. (Volochinov). Marxismo e filosofia da linguagem. Trad. de Michel Lahud e Yara Frateschi. 9 ed. São Paulo: Hucitec, 1999. 
. Estética da Criação Verbal. São Paulo: Martins Fontes, 1992.

BARROS, Diana Luz Pessoa de. Teoria semiótica do texto. São Paulo: Ática, 1988 (1990 e 2005).

BERTRAND, Dénis. Caminhos da semiótica literária. Bauru: Edusc, 2003.

BRAIT, Beth (org.). Bakhtin: conceitos-chave. São Paulo: Contexto, 2005.

BRASIL. Secretaria da Educação Fundamental. Parâmetros Curriculares Nacionais: terceiro e quarto ciclos do Ensino Fundamental - Língua Portuguesa. Brasília: MEC/ SEF, 1998.

DISCINI, Norma. A comunicação nos textos: leitura, produção e exercícios. São Paulo: Contexto, 2012. . HQ e charge. In: LOPES, Ivã Carlos.; HERNANDES, Nilton. (Org).

Semiótica, objetos e práticas. São Paulo: Contexto, 2005.

CORTINA, Arnaldo. Semiótica e leitura: os leitores de Harry Potter. In:

MARCHEZAN, Renata Coelho (Org.) Razões e sensibilidades: A semiótica em foco. Araraquara: Laboratório Editorial/FCL/UNESP; São Paulo: Cultura Acadêmica Editora, 2004.

FIORIN, José Luiz; SAVIOLI; FRANCISCO Platão. Para entender o texto: leitura e redação. São Paulo: Ática, 1992.

. Lições de texto: leitura e redação. São Paulo: Ática, 1996.

Elementos de análise do discurso. São Paulo: Contexto,

1999.

FLOCH, Jean Marie. Documentos de Estudo do Centro de Pesquisas

Sociossemióticas - 1. São Paulo: Centro de Pesquisas Sociossemióticas, 2001.

GREIMAS, A. J.; COURTÉS, J. Dicionário de Semiótica. São Paulo: Cultrix. s/d.

HOUAISS, Antônio; VILLAR, Mauro de Salles. Dicionário Houaiss da Língua

Portuguesa. Rio de Janeiro: Objetiva, 2001.

LAVOURA ARCAICA. Direção de Luiz Fernando Carvalho. Brasil: Europa Filmes, 2001. DVD (172 min), son., color. Baseado no romance "Lavoura Arcaica" de Raduan Nassar.

MARTIN, Marcel. A linguagem cinematográfica. São Paulo: Brasiliense, 2003.

LIMOLI, Loredana. Semiótica e ensino: práticas pedagógicas de leitura. Anais do $53^{\circ}$

Seminário do Gel. Taubaté, 2003. 
Leitura da imagem e ensino de língua materna. In: LIMOLI, Loredana;

MENDONÇA, Ana Paula Ferreira de (Org.). Nas fronteiras da linguagem: leitura e produção de sentido. Londrina: Editorial Mídia, 2006.

NASSAR, R. Lavoura Arcaica. 3. ed. São Paulo: Companhia das letras, 1989.

PALMA, Glória Maria (Org.). Literatura e cinema: A demanda do Santo Graal \& Matrix / Eurico, o presbítero \& A máscara do Zorro. Bauru, SP: EDUSC, 2004.

BRASIL. Secretaria da Educação Fundamental. Parâmetros Curriculares Nacionais: terceiro e quarto ciclos do Ensino Fundamental - Língua Portuguesa. Brasília: MEC/ SEF, 1998.

PIETROFORTE. Antonio Vicente. Semiótica visual: o percurso do olhar. São Paulo: Contexto, 2004.

ROJO, Roxane (org.). A prática de linguagem em sala de aula: praticando os PCN. São Paulo: Mercado de Letras, 2000.

2009 . Letramentos múltiplos, escola e inclusão social. São Paulo: Parábola Editorial, . (Org.). Escola Conectada: os multiletramentos e as TICs. São Paulo: Parábola, 2013.

TEIXEIRA, Lucia. Para uma metodologia de análise de textos verbovisuais. In: OLIVEIRA, Ana Claudia. Linguagens na comunicação: desenvolvimentos de semiótica sincrética. São Paulo: Estação das Letras e Cores, 2009.

XAVIER, Ismail. O discurso cinematográfico: a opacidade e a transparência. São Paulo: Paz e Terra, 2005. 


\section{ANEXO}

\section{RESPOSTAS DAS ATIVIDADES}

\section{Atividade 1}

a) Pedro é o irmão mais velho, portanto representante do pai no núcleo familiar. Seu discurso "Abotoe a camisa, André" ratifica o discurso autoritário do pai. Pedro era uma extensão das palavras de ordem do pai.

b) No texto Lavoura Arcaica, há a projeção pressuposta de uma pessoa "eu", sujeito André, estabelecendo uma relação de sentido subjetiva. Exemplos: "dei logo uns passos e abri uma das folhas"; "era num sítio lá do bosque que eu escapava aos olhos apreensivos da família" (grifos nossos).

c) Resposta pessoal. Sugestão: Se a projeção pressuposta fosse "ele", a relação de sentido seria objetiva, imparcial, de distanciamento, portanto o texto teria mais credibilidade.

d) O narrador fala de seu passado, são lembranças. Vários verbos comprovam isso, como "dei", "abri”, "era", "entrou”, entre outros.

e) O passado influenciou o presente de André de forma negativa, ele estava em estado de opressão: "eu senti nos seus braços o peso dos braços encharcados da família inteira", "eu senti a força poderosa da família desabando sobre mim como um aguaceiro pesado".

f) Resposta pessoal.

g) O narrador fala de suas lembranças do passado. O passado é restaurado para dar sentido a seu presente, nesse processo de retomada. As lembranças são ressignificadas a partir de seu presente. Sua história é uma dimensão do passado, ressignificada no aqui e agora, como representativa de sua solidão e de sua opressão vivenciada junto à família. Se o narrador falasse exatamente como foi o passado, seria uma narração mais objetiva, sem um novo significado às lembranças do passado.

h) O verbo "dei", em "dei logo uns passos", no início do texto, já revela uma ação pontual, está no pretérito perfeito, portanto a enunciação dos fatos é posterior ao acontecimento narrado. Os verbos, nesse fragmento, descrevem ações de André (narrador), marcando sua presença de forma viva, em ações já concluídas. No texto, no momento em que André narra suas lembranças, o verbo utilizado é o pretérito imperfeito, uma ação não acabada ou que se repetia "era", como em "era num sítio". Nos dois casos, a fala de quem conta a história é posterior à história contada, por isso os verbos no pretérito.

i) O enunciador do texto dá voz a André, pessoa da enunciação já instalada no enunciado. $\mathrm{O}$ eu, nesse caso, registra por meio de uma debreagem enunciativa e de uma enunciva, um eu e um ele no discurso. $\mathrm{O}$ eu com valor de ele manifesta-se como interlocutor de um diálogo "não te esperava", que tem como interlocutário 
(tu) o irmão Pedro. Pedro (ele) faz uma debreagem enunciativa, instaurando um eu no discurso "nós te amamos muito". Com esse tipo de recurso, o discurso provoca sensação de presente enunciativo no interior do tempo passado, como também produz um efeito de verdade, criando a ilusão de situação "real" de diálogo.

j) A história de André é uma dimensão do passado. Quando fala do passado, o bosque, a fazenda, por exemplo, ele alude a um espaço datado e materializado no passado, no lá, e a partir de um espaço-tempo do passado que projeta um olhar sobre o presente, o aqui, ressignificado: um lugar onde podia brincar, estar livre e liberto.

\section{Atividade 2}

a) A embreagem acontece quando o pai diz ao filho André "Faça um esforço, meu filho, seja mais claro, não dissimule, não esconda nada do teu pai", suspendese a oposição entre en e ele, empregando-se a terceira pessoa (teu (seu) pai) em lugar da primeira (de mim).

b) No discurso de André, algumas figuras são: história, pai, sol a sol, fome, corpo, dentes, pés, mundo, prisioneiro, casa, carcereiro, membro, abraço, afeto, aleijão, mãos, algoz, canga, boi, pescoço, etc.

No discurso do pai: água, luz, palavra, soberba, milênios, casa, ideias, poeira, olhos, cegueira, escuridão, árvore, frutos, semente, grão, dias, pensamento, língua, família, etc.

c)

\begin{tabular}{|l|l|l|l|}
\hline \multicolumn{1}{|c|}{ Sujeitos/Ator } & \multicolumn{1}{|c|}{ Figuras } & \multicolumn{1}{c|}{$\begin{array}{c}\text { Percurso } \\
\text { Figurativo }\end{array}$} & \multicolumn{1}{c|}{ Temas } \\
\hline André & $\begin{array}{l}\text { Prisioneiro, } \\
\text { carcereiro, aleijão, } \\
\text { membros, mãos, pés, } \\
\text { algoz, boi, pescoço, } \\
\text { canga }\end{array}$ & Da raiva & Da Revolta \\
\hline Pai & $\begin{array}{l}\text { Água, palavra, casa, } \\
\text { cegueira, escuridão, } \\
\text { frutos, semente, grão, } \\
\text { família, milênio, dias, } \\
\text { família }\end{array}$ & Da autoridade & Da Opressão \\
\hline
\end{tabular}

d) Sugestão: A partir das figuras presentes nesse fragmento, chega-se à isotopia da universalização, ou seja, a fragmentação histórica do sujeito, dos problemas enfrentados pela família e pelo homem, mesmo que sejam problemas e situações projetadas em tempo e espaço diferentes no decorrer da história do homem. Essa isotopia é uma síntese das relações e conflitos das famílias. O ciclo da família de André é o mesmo de muitas famílias, as histórias se repetem, mas o 
homem continua praticamente o mesmo, e esse ciclo da intemporalidade é uma imagem da universalização encontrada nos conflitos de André.

\section{Atividade 3}

a) Sugestão: Literatura e cinema são modalidades artísticas diferentes. A transmutação da linguagem literária para a linguagem audiovisual resulta em algumas transformações, inevitáveis diante da mudança de veículo, dos contextos diferentes, e modos de produção. Essas transformações resultam em uma nova obra, independente, sujeita a comparações e críticas.

b) É uma suposta debreagem temporal enunciva, pois quem assiste ao filme está no tempo presente, todas as imagens que se vê estão acontecendo no presente do indicativo. O momento de referência é o presente, cuja concomitância se dá no momento do acontecimento, o presente do presente, por isso se diz que o cinema é a arte do presente. É a partir dele que se visualiza debreagens e embreagens, sejam elas enunciativas ou enuncivas. A história de André ocorre, então, nessa concomitância, cujo momento de referência é o presente.

c) A partir da chegada de Pedro ao quarto de pensão, há a debreagem enunciativa de segundo grau, as vozes do interlocutor (André) e do interlocutário (Pedro). Tem-se instaurada uma anterioridade também enunciativa. $\mathrm{O}$ efeito de sentido é o de subjetividade, aproximação, parcialidade.

d) $\mathrm{O}$ recurso visual que sugere a presentificação de uma anterioridade do presente, evocada pela embreagem enunciativa, no momento de referência presente, foi o corte das imagens. Pedro, ao chegar ao quarto, abraça o irmão e diz "Abotoe a camisa, André". No momento de referência presente, instaurada pelo agora (figs. 01 e 02), há um corte de imagens, instaurando uma anterioridade também enunciativa, André se recorda das tardes na fazenda, quando criança (figs 03 e 04), enunciando, em voz off "Na madorra das tardes vadias na fazenda, era num sítio lá do bosque que eu escapa aos olhos apreensivos da família". Há também a instauração do cromatismo nas imagens. Há uma mudança significativa em relação ao sentimento interno de André ao relatar seu encontro com o irmão e suas lembranças da infância. No quarto há pouca luz, e muitas sombras, produzindo efeito de uma interioridade fechada, nebulosa, angustiada. Ao se lembrar da infância, em nova sequência, o claro sobressai, revelando lembranças de uma infância mais pura, inocente. Assim, o corte e o cromatismo instauraram a presentificação de uma anterioridade do presente.

e) $\mathrm{O}$ espaço exterior às memorias do ator do enunciado é instaurado por uma debreagem enunciativa, colocando o aqui na diegese narrativa. Os espaços do albures/algures relacionados pelas memórias do ator do enunciado manifestamse em contraponto ao aqui inserido inicialmente, por meio de uma debreagem enunciva de segundo grau. Tem-se, portanto, o alhures/algures representado pelo espaço inscrito no enunciado. Quando os flashbacks são acionados, há o efeito de sentido da presentificação de algo que estava fora da situação de enunciação entre interlocutor e interlocutário. 
f) O narrador é explicitado. O próprio André é o personagem-narradorprotagonista, projeção enunciativa. Nesse processo, ao instaurar o narrador, há uma debreagem de primeiro grau; e, ao instalar as personagens, na interlocução, ocorre uma debreagem de segundo grau (discurso direto). O efeito de sentido é de subjetividade, parcialidade, aproximação.

g)

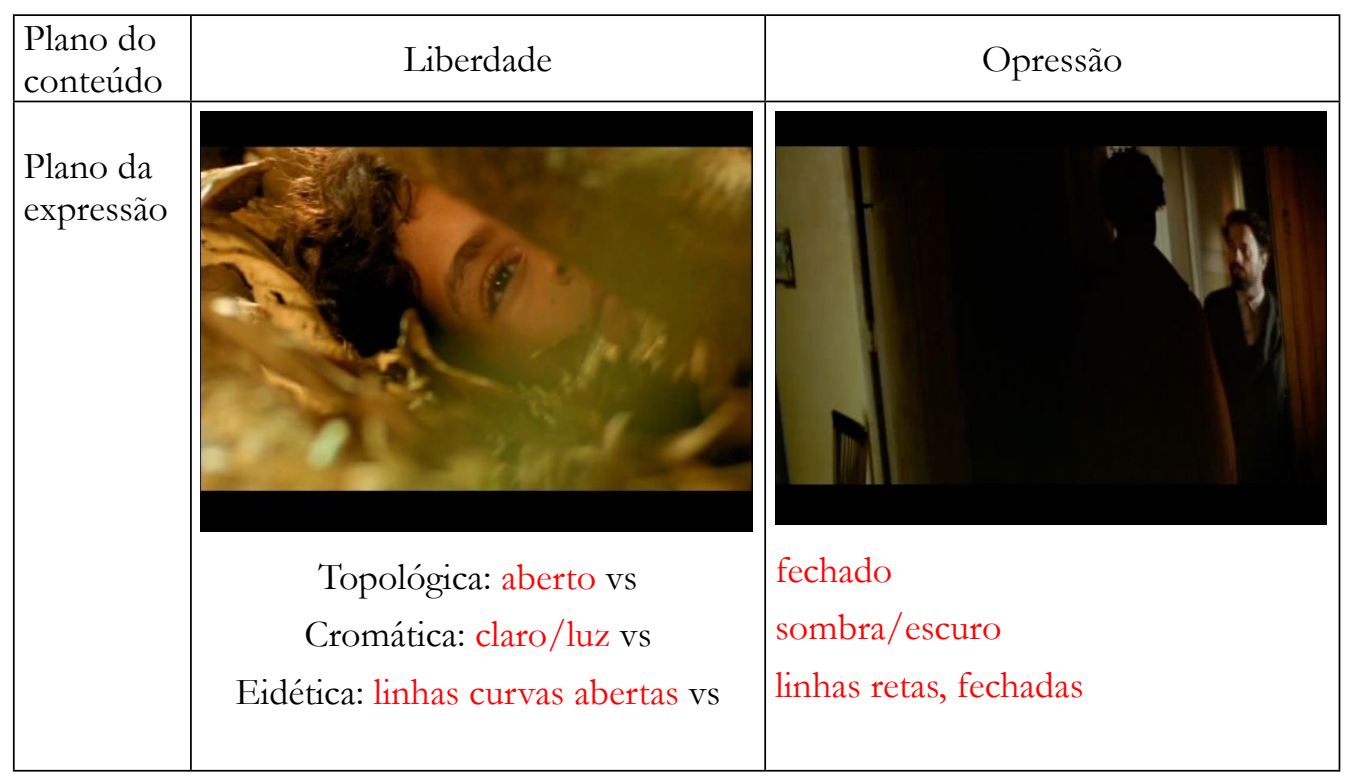

\section{Atividade 4:}

a) O quarto está bastante escuro. A câmera somente enquadra o drama de André, deixando o resto do quadro no escuro. A iluminação é dramática, esculpindo as sombras e os rostos dos irmãos, criando uma obscuridade voltada para a interioridade das personagens.

b) $\mathrm{Na}$ montagem, os planos se alternam para compor o quadro, plano conjunto nos dois irmãos sentados no assoalho, figs. 05 e 06 . Um segundo plano (americano) revela André pegando uma caixa com quinquilharias, fig. 06, que ganhou de prostitutas; a câmera desloca-se para baixo do quadro até detalhar André espalhando os objetos da caixa no chão, fig. 07. Detalhe primeiro plano nas mãos se misturando aos objetos. Diz ao irmão "Pedro, pega na mão e sinta essa fitinha imunda". A câmera reitera o mesmo enquadramento do plano mais aproximado nas mãos com a fita entre os dedos, fig. 08, em meio a muita delicadeza. Depois, em 
campo-contra-campo ${ }^{13}$, ora com foco em André, ora em Pedro, alisando a fita, figs. 09 e 10. Vários minutos para a narração de André com cenas intercaladas de sua comunhão com as prostitutas.

c) Há sons humanos: narração agressiva, respiração ofegante, manifestação de desespero, fig. 13-14, intensificando a alta voltagem emocional; como também uma discreta música ao fundo, somente para intensificar o drama narrado e aprofundar a sensibilidade.

d) Incrível o efeito que o movimento da lâmpada faz nas personagens, alternando o claro e o escuro em seus rostos. A lâmpada contribui para criar uma atmosfera ambígua e ao mesmo tempo esculpe as sombras, intervindo como fator de dramatização dentro daquele espaço pequeno do quarto. $\mathrm{O}$ quarto parece menor, sufocante, compondo o interior da personagem, amalgamado ao seu corpo. Articula-se aqui um paralelismo, entre espaço interno e externo. $\mathrm{O}$ espaço externo em meio às sombras; o interno, um furacão de sentimentos contraditórios que irá explodir de forma desordenada.

\section{Atividade 5: Produçáo de texto pelo aluno}

13 Campo/contra-campo é um procedimento chave num cinema dramático construído dentro dos princípios da identificação. Seu ponto de aplicação máxima se dá na filmagem de diálogos. Ora a câmera assume o ponto de vista de um, ora de outros dos interlocutores, fornecendo uma imagem da cena da alternância de pontos de vista diametralmente opostos (daí a origem da denominação campo/contra-campo). Com esse procedimento, o espectador é lançado para dentro do espaço do diálogo. Ele, ao mesmo tempo, intercepta e identifica-se com duas direções de olhares, num efeito que se multiplica pela sua percepção privilegiada das duas séries de reações expressas na fisionomia e nos gestos das personagens (XAVIER, 2005, p. 35). 